\title{
Nutritive value and physical characteristics of Xaraes palisadegrass as affected by grazing strategy
}

\author{
R.L.G. Nave ${ }^{1}$, C.G.S. Pedreira ${ }^{2 \#}$ and B.C. Pedreira ${ }^{2}$ \\ ${ }^{1}$ Department of Horticulture and Crop Sciences, Ohio State University - Columbus, Ohio, USA \\ ${ }^{2}$ Departamento de Zootecnia. ESALQ-Universidade de Sao Paulo. Av. Padua Dias 11, \\ Piracicaba, SP, 13418-900, Brazil
}

\begin{abstract}
The aim of this study was to ascertain whether the defoliation frequency based on a fixed rest period would generate variable sward structural and physiological conditions at each subsequent grazing event. The relative importance of the physiological age was established in comparison with the chronological age in the determination of the forage nutritive value of Xaraes palisadegrass [Brachiaria brizantha (Hochst ex A. RICH.) STAPF. cv. Xaraes]. Two grazing frequencies were defined by light interception (LI) at initiation of grazing (95\% LI - "target grazing” [TG] or 100\% LI - "delayed grazing” [DG]) and one based on chronological time, grazing every 28 days (28-d). Forage produced under the TG schedule was mostly leaves (93\%) with a higher concentration of crude protein (CP; $138 \mathrm{~g} / \mathrm{kg}$ in the whole forage), a lower concentrations of neutral detergent fibre (NDF) in the stems $(740 \mathrm{~g} / \mathrm{kg})$, and higher in vitro dry matter digestibility (IVDMD) of the leaves (690 $\mathrm{g} / \mathrm{kg}$ ), compared to the other treatments. Lower grazing frequency strategies (DG and 28-d) resulted in forage with higher proportions of stems (10 and 9\%, respectively). Strategies based on light interception did not produce pre-graze forage with a uniform nutritive value, as the indicators varied across grazing cycles. The treatment based on fixed days of rest did not result in uniformity.
\end{abstract}

Keywords: Digestibility, light interception, shearing resistance, forage quality

\# Corresponding author. Email: cgspedreira@usp.br

\section{Introduction}

Ruminant performance depends directly on forage quality (nutritive value and voluntary intake) and its interaction with rumen microorganisms in the digestion process. Normally, high concentrations of crude protein and digestible dry matter are not easily found in tropical forages (Wilson, 1993; 1997) and, although this has been associated with intrinsic tropical grass characteristics, in most cases this is magnified by the fact that the management of these species under grazing is inadequate and results in overly mature forage being offered to the grazing animal. In this context, maturity is a main factor affecting tropical forage nutritive value, and the environment can markedly affect maturity by modifying the chemical composition of plant parts, or acting on plant morphology, such as on leaf : stem ratios (Sinclair \& Seligman, 1995).

In most forage evaluation protocols, plant adaptation and yield potential are often emphasised and, only in the final stages before commercial release, nutritive value and intake are ascertained in animal trials. This can result in the early discarding of genotypes that, although not as well adapted or productive as others, can produce high-quality forage.

Studies to better characterize the quality of forages by their physical properties have considered techniques such as the resistance to grinding (Minson \& Cowper, 1974) and to shearing (Mackinnon et al., 1988). Evidence exists that shearing resistance is related to chemical composition, especially to the cell wall and its components (Wilson, 1997; Hughes et al., 2000; Nave et al., 2009). These evaluations can help to explain the reasons that lead to differences in feed degradation in materials of similar composition but contrasting physical characteristics, which can affect the access and colonization of feedstuffs by ruminal microorganisms (Giger-Reverdin, 2000). Therefore, understanding the interplay between quantitative (e.g. productivity) and qualitative (e.g. chemical composition and digestibility, plus the physical traits that can affect nutritive value) characteristics of forages, is key to the identification of the variables that impact the outputs of a forage production system, namely animal performance and productivity.

Xaraes palisadegrass [Brachiaria brizantha (Hochst ex A. RICH.) STAPF. cv. Xaraes] was released as a promising option for the Brazilian beef cattle industry, and has potential for use in many other 
tropical/subtropical locations around the globe. However, data on its productive (Pedreira \& Pedreira, 2007; Pedreira et al., 2009) and qualitative responses to defoliation management are still scarce (Euclides et al., 2000, Flores et al., 2008) under a wide range of grazing management practices. The objective in this study was to ascertain whether the defoliation frequency based on a fixed pasture rest period ("chronological age") would generate variable sward structural and physiological conditions at each grazing as compared with grazing schedules based on fixed sward conditions ("physiological age"), expressed as levels of light interception by the sward. In addition, an attempt was made to establish the relative importance of the physiological age in comparison with the chronological age in determining the indicators (chemical and physical) of the forage nutritive value of Xaraes palisadegrass.

\section{Material and Methods}

The experiment was carried out at Piracicaba, Sao Paulo, Brazil (22,42 S; 47,30 W; elevation 580 m). The soil is classified as Kandiudalfic Eutrudox (Soil Survey Staff, 2006), and was highly fertile, requiring no corrections or amendments when the experiment started. Only production fertilizations, totalling $120 \mathrm{~kg} N / \mathrm{ha}$ and $100 \mathrm{~kg} \mathrm{~K} / \mathrm{ha}$ during the experimental period were applied as $\left(\mathrm{NH}_{4}\right)_{2} \mathrm{SO}_{4}$ and $\mathrm{KCl}$, respectively. Rainfall and temperature data were collected at a weather station located $1 \mathrm{~km}$ from the experimental site.

The trial was set as a completely randomized design with three treatments and three field replications. Nine experimental units ( 14 x 8.5 m paddocks) were mob-grazed so as to mimic paddocks under rotational stocking, according to treatments assigned to each paddock. Treatments corresponded to three grazing strategies; one of a fixed rest period (grazing every 28 days, 28-d) and two with variable rest periods. The variable rest periods were defined based on what would supposedly be a target, optimum interval, established so that the sward intercepted $95 \%$ of incoming radiation, and this was named a "target grazing" (TG) strategy. The other variable rest period strategy was chosen so as to represent a condition where grazing is delayed (“delayed grazing” [DG]), either voluntarily (e.g. stockpiling or deferred grazing) or involuntarily (e.g. intensive production not adequately accompanied by timely harvest or grazing). This was defined as when light interception (LI) by the pasture canopy was almost complete, in our case equal or above $97.5 \%$ in two consecutive, twice-a-week measurements. In each paddock, whenever the specific treatment condition was achieved, animals (2 to 6) were brought in and grazed until a15 cm stubble was reached.

The grazing cycles occurred on the following dates: TG strategy (13 Oct. 2005 - cycle 1; 01 Nov. 2005 - cycle 2; 02 Dec. 2005 - cycle 3; 20 Dec. 2005 - cycle 4; 09 Jan. 2006 - cycle 5; 06 Feb. 2006 - cycle 6); DG strategy (24 Oct. 2005 - cycle 1; 05 Dec. 2005 - cycle 2; 02 Jan. 2006 - cycle 3; 20 Dec 2005 - cycle 4; 08 Feb. 2006) and 28-d (20 Oct. 2005 - cycle 1; 18 Nov. 2005 - cycle 2; 15 Dec. 2005 - cycle 3; 13 Jan. 2006 cycle 4; 14 Feb. 2006 - cycle 5). Measurements of LI and sward height were made during every regrowth (rest period), initiating immediately after grazing, continuing weekly, and immediately before the following grazing, in order to characterize the structural variations of the sward. Light interception was measured using a model LAI 2000 canopy analyzer (LI-COR, Lincoln Nebraska, EUA) (Welles \& Norman, 1991).

After the swards were conditioned to their respective grazing schedules (for two months prior to the beginning of data collection) forage samples were collected immediately before each grazing. Within each paddock 15 to 20 sites that represented mean sward condition were selected and hand-plucked samples were collected above the $15 \mathrm{~cm}$ stubble and taken to the laboratory. Each composite sample, weighing approximately $2 \mathrm{~kg}$ (fresh forage), was then separated and a sub-sample of $700 \mathrm{~g}$ was dried in a forced air oven at $60{ }^{\circ} \mathrm{C}$ to a constant weight (48 - $72 \mathrm{~h}$ ). The remaining material (approximately $1.3 \mathrm{~kg}$ ) was separated in its plant-part components (green stems, green leaves and dead material). The dead material was dried at $60{ }^{\circ} \mathrm{C}$ to a constant weight. From the leaf fraction another sub-sample was taken, including leaves of all categories (young to mature) for a total of 20 leaf blades. Shearing resistance of these leaf blades was measured in a Warner-Bratzler Meat Shear at the midpoint of their length. The same procedure was followed for the stem fraction. The sheared material was subsequently returned to their respective sub-samples and dried at $60{ }^{\circ} \mathrm{C}$ to a constant weight.

Dried samples of the leaves and whole forage were tested for grinding resistance. For that evaluation, samples were first ground in a Wiley mill to pass a $5 \mathrm{~mm}$ screen. Twenty grams of this material were then ground through a $1 \mathrm{~mm}$ screen, for 25 seconds. The ground material $(1 \mathrm{~mm})$ and the unground residue $(5 \mathrm{~mm}$ that did not pass the screen and remained in the grinding chamber) of these sub-samples were then collected and weighed. Grinding resistance was calculated as the proportion of the initial $20 \mathrm{~g}$ that did not pass through 
the $1 \mathrm{~mm}$ screen. Thus, material with higher resistance to grinding was those where the $5 \mathrm{~mm}$ residue (not ground to $1 \mathrm{~mm}$ ) was higher (Hughes et al., 1998).

All samples were subsequently ground in a Wiley mill with a $1 \mathrm{~mm}$ screen and taken to the laboratory for chemical analyses. Crude protein (CP) concentration was determined using the Dumas combustion method, with a LECO FP-528 automatic nitrogen (N) analyzer (Wiles et al., 1998). In vitro dry matter digestibility (IVDMD) was determined by the ANKOM Fibre Analyzer (ANKOM Technology Corporation, Fairport, NY) protocol described by Holden (1999). Concentrations of neutral detergent fibre (NDF) and acid detergent fibre (ADF) were determined using the sequential method of the ANKOM Fibre Analyser (ANKOM Technology Corporation, Fairport, NY), described by Holden (1999). The results of IVDMD were atypically high and a correction factor was applied after the analysis of IVDMD by the Tilley \& Terry (1963) method in half of the samples. The correction factor was generated by regressing the IVDMD values measured by the ANKOM method against those of the same samples estimated by the Tilley \& Terry (1963) method. The regression model generated was $\mathrm{y}=27.4193+0.055061 \mathrm{x}$, where $\mathrm{y}$ is the value of the corrected digestibility and $\mathrm{x}$ is the value of the digestibility found by the ANKOM method.

The data were analysed using the MIXED procedure of SAS (Littell et al., 2006). In this analysis "grazing cycle" (the sequence of grazing events within each treatment) was considered a random effect, while the "grazing method" was considered a fixed effect. Significance was detected at the 0.05 level of probability.

\section{Results and Discussion}

The pastures grazed every 28 days or under the DG strategy resulted in forage with different plant part compositions compared with that in paddocks managed at TG (Table 1). The TG strategy resulted in six grazing cycles, with shorter rest periods and a higher accumulation of leaves. The other treatments resulted in longer intervals between grazing, and lower leaf : stem ratios. During the experiment it became evident that the stem fraction was proportionally higher in treatments with low grazing frequencies, whereas the forage in paddocks grazed more frequently (e.g. 95\% LI) consisted mostly of leaves (93\%). In a companion study in the same experimental area, DG resulted in a longer mean interval between grazings and higher herbage accumulation (22760 kg DM/ha) than the other two treatments (mean $=17700 \mathrm{~kg} \mathrm{DM} / \mathrm{ha}$ ) (Pedreira et al., 2007).

Long rest periods increase the possibilities for a plant community to replenish the reserves needed to restore the canopy. If, however, intervals are too long, allowing for the canopy to intercept almost all the incident light, stem elongation is triggered, changing the dynamics of forage accumulation and often resulting in ever-increasing post-graze stubble mass, especially in tropical grass species (Da Silva \& Sbrissia, 2001; Braga et al., 2009). The proportion of stems in rotational grazing are more closely related to defoliation frequency, as reported for Mombaça guineagrass (Panicum maximum Jacq.) by Carnevalli et al. (2006), who measured higher proportion of stem on pastures grazed less frequently (DG). In the present study, TG resulted in the lowest proportion of stems (5\%) and DG and 28-d resulted in higher proportions $(10 \%)$ in the pre-graze forage.

Concentration of CP (Table 2) differed among treatments for the stem $(\mathrm{P}=0.021)$ and whole forage $(\mathrm{P}=0.023)$, but not for the leaf $(\mathrm{P}=0.095)$. Paddocks under the TG strategy produced forage with higher

Table 1 Proportion ( \pm s.e.) of leaf, stem and dead material of pre-graze forage above $15 \mathrm{~cm}$ in Xaraes palisadegrass pastures under three grazing strategies $(n=6,4$, and 5 , for TG, DG and 28-d, respectively)

\begin{tabular}{lccc}
\hline Strategy & Leaf (\%) & Stem (\%) & Dead Material (\%) \\
\hline TG & $92.5^{\mathrm{a}} \pm 0.7$ & $5.4^{\mathrm{b}} \pm 0.5$ & $2.2 \pm 0.3$ \\
DG & $88.4^{\mathrm{b}} \pm 0.9$ & $9.7^{\mathrm{a}} \pm 0.9$ & $1.9 \pm 0.3$ \\
28-d & $88.4^{\mathrm{b}} \pm 1.0$ & $9.4^{\mathrm{a}} \pm 1.0$ & $2.2 \pm 0.4$ \\
P-value & 0.001 & 0.001 & 0.744 \\
\hline
\end{tabular}

${ }_{\mathrm{a}, \mathrm{b}}$ Column means with different superscripts differ significantly at $\mathrm{P}<0.05$.

TG - Target grazing; DG - Delayed grazing; 28-d - Fixed rest period. 
Table 2 Mean seasonal nutritive value (chemical composition and digestibility; \pm s.e.) of Xaraes palisadegrass forage (leaf and stem fractions, and whole forage) under three different grazing strategies ( $\mathrm{n}=6$, 4, and 5, for to TG, DG, and 28-d, respectively) (Dry matter basis)

\begin{tabular}{|c|c|c|c|}
\hline Strategy & Leaf (g/kg) & Stem (g/kg) & Whole forage (g/kg) \\
\hline & \multicolumn{3}{|c|}{ Crude protein } \\
\hline TG & $141 \pm 6$ & $89^{\mathrm{a}} \pm 4$ & $138^{\mathrm{a}} \pm 6$ \\
\hline DG & $133 \pm 7$ & $79^{\mathrm{ab}} \pm 5$ & $122^{\mathrm{ab}} \pm 6$ \\
\hline \multirow[t]{2}{*}{ 28-d } & $123 \pm 5$ & $72^{b} \pm 5$ & $116^{\mathrm{b}} \pm 4$ \\
\hline & \multicolumn{3}{|c|}{ Neutral detergent fibre } \\
\hline TG & $675 \pm 7$ & $740^{\mathrm{b}} \pm 5$ & $678 \pm 6$ \\
\hline DG & $688 \pm 7$ & $769^{a} \pm 8$ & $682 \pm 7$ \\
\hline \multirow[t]{2}{*}{ 28-d } & $685 \pm 5$ & $758^{\mathrm{a}} \pm 5$ & $692 \pm 5$ \\
\hline & \multicolumn{3}{|c|}{ Acid detergent fibre } \\
\hline TG & $348 \pm 5$ & $396^{\mathrm{b}} \pm 4$ & $349 \pm 5$ \\
\hline DG & $355 \pm 4$ & $414^{\mathrm{a}} \pm 6$ & $351 \pm 4$ \\
\hline \multirow[t]{2}{*}{ 28-d } & $356 \pm 4$ & $416^{\mathrm{a}} \pm 4$ & $360 \pm 3$ \\
\hline & \multicolumn{3}{|c|}{ In vitro dry matter digestibility } \\
\hline TG & $693^{\mathrm{a}} \pm 4$ & $660^{\mathrm{a}} \pm 5$ & $698 \pm 4$ \\
\hline DG & $680^{b} \pm 5$ & $635^{b} \pm 7$ & $695 \pm 5$ \\
\hline 28-d & $678^{\mathrm{b}} \pm 3$ & $657^{\mathrm{a}} \pm 5$ & $689 \pm 4$ \\
\hline
\end{tabular}

concentrations of $\mathrm{CP}$ in both the stem and whole forage, contrasting with paddocks grazed every 28 days, where forage $\mathrm{CP}$ levels were lower. There was a cyclic effect $(\mathrm{P}=0.042)$ on whole forage $\mathrm{CP}$ concentration for paddocks grazed at TG (Table 3$)$, but not for leaf $(\mathrm{P}=0.071)$ nor for stem $(\mathrm{P}=0.013)$. Forage from paddocks grazed every 28 days (Table 4 ) had $\mathrm{CP}$ concentrations affected by cycle in leaves $(\mathrm{P}=0.0001)$, stems $(\mathrm{P}=0.0002)$ and whole forage $(\mathrm{P}=0.0001)$. In the $\mathrm{DG}$ strategy, there was a cyclic effect for CP in all plant components (Table 5), with $\mathrm{P}=0.007, \mathrm{P}=0.004$ and $\mathrm{P}=0.031$ for leaves, stems and whole forage, respectively. Research on Marandu palisadegrass clipped at increasing rest intervals (Mari et al. 2003) showed a trend for reduction in CP concentration with increasing maturity (varying from 132 to $67 \mathrm{~g} / \mathrm{kg}$ ). The higher CP concentration found in forage harvested early in the vegetative stage was associated with a high proportion of leaves.

Concentrations of NDF (Table 2) differed among treatments in the stems ( $P=0.007)$, but not in the leaves nor in the whole forage ( $\mathrm{P}=0.401$ and $\mathrm{P}=0.173$, respectively). The TG treatment resulted in forage with lower NDF concentrations in the stems. The concentration of ADF in pre-graze forage (Table 2) was similar to that of NDF, and the DG and 28-d treatments resulted in forage with higher ADF concentrations in stems. There was no effect of treatments on leaf ADF $(P=0.377)$ and whole forage ADF $(P=0.091)$.

There was no grazing cycle effect on paddocks under the DG strategy (Table 5) for NDF concentration in the leaves $(\mathrm{P}=0.267$, mean $=688 \mathrm{~g} / \mathrm{kg})$, stems $(\mathrm{P}=0.134$, mean $=769 \mathrm{~g} / \mathrm{kg})$ and whole forage $(\mathrm{P}=0.653$, mean $=682 \mathrm{~g} / \mathrm{kg}$ ). Under the TG strategy (Table 3) there was a cyclic effect on NDF concentrations in the leaf $(\mathrm{P}<0.001)$, whole forage $(\mathrm{P}=0.001)$ and stem $(\mathrm{P}=0.032)$. Paddocks grazed every 28 days (Table 4) produced forage with NDF concentrations varying over cycles in stems $(\mathrm{P}=0.001)$ and whole forage $(P=0.003)$, but not in leaves $(P=0.280)$. NDF in leaves and whole forage did not differ across treatments, and this is consistent with the NDF concentration in the whole forage, which was the same, since the relative amount of stem in whole forage samples was quite low. NDF concentrations increased as autumn approached, mainly in the TG and in the 28-d treatments, but were lower (ranging from $679 \mathrm{~g} / \mathrm{kg}$ to 694 $\mathrm{g} / \mathrm{kg}$ ) than the $734 \mathrm{~g} / \mathrm{kg}$ found by Euclides (2002) in Xaraes palisadegrass. Higher NDF levels at the end of the growing season were likely associated with increased flowering. Considering all grazing cycles, although there was a treatment effect on the concentration of NDF in stems, this cannot account for NDF differences in whole forage, because the proportion of stems was very low. The same happened in ADF concentration. 
Table 3 Grazing cycle effect on qualitative responses of Xaraes palisadegrass forage (leaf and stem fractions, and whole forage) managed under the "target grazing” (TG) strategy (Dry matter basis)

\begin{tabular}{|c|c|c|c|c|c|c|c|}
\hline \multirow{2}{*}{ Response } & \multicolumn{6}{|c|}{ Grazing cycle } & \multirow{2}{*}{ s.e.m } \\
\hline & 1 & 2 & 3 & 4 & 5 & 6 & \\
\hline CP leaf (g/kg) & 165 & 155 & 131 & 163 & 125 & 105 & 26 \\
\hline CP stem (g/kg) & 100 & 98 & 81 & 104 & 80 & 72 & 14 \\
\hline CP whole (g/kg) & $164^{\mathrm{a}}$ & $149^{\mathrm{b}}$ & $130^{\mathrm{bc}}$ & $156^{\mathrm{ab}}$ & $124^{\mathrm{cd}}$ & $103^{\mathrm{d}}$ & 26 \\
\hline NDF leaf (g/kg) & $650^{\mathrm{b}}$ & $645^{\mathrm{b}}$ & $700^{\mathrm{a}}$ & $654^{\mathrm{b}}$ & $710^{\mathrm{a}}$ & $692^{\mathrm{a}}$ & 30 \\
\hline NDF stem (g/kg) & $728^{\mathrm{b}}$ & $728^{\mathrm{ab}}$ & $743^{\mathrm{ab}}$ & $741^{\mathrm{ab}}$ & $747^{\mathrm{ab}}$ & $755^{\mathrm{a}}$ & 22 \\
\hline NDF whole (g/kg) & $645^{\mathrm{b}}$ & $645^{\mathrm{b}}$ & $692^{\mathrm{ab}}$ & $698^{\mathrm{a}}$ & $698^{\mathrm{a}}$ & $697^{\mathrm{a}}$ & 26 \\
\hline ADF leaf (g/kg) & $334^{\mathrm{b}}$ & $321^{\mathrm{b}}$ & $365^{\mathrm{a}}$ & $336^{\mathrm{b}}$ & $372^{\mathrm{a}}$ & $357^{\mathrm{a}}$ & 21 \\
\hline ADF stem (g/kg) & 389 & 393 & 404 & 404 & 383 & 392 & 18 \\
\hline ADF whole (g/kg) & $328^{\mathrm{b}}$ & $327^{\mathrm{b}}$ & $359^{\mathrm{a}}$ & $357^{\mathrm{a}}$ & $360^{\mathrm{a}}$ & $361^{\mathrm{a}}$ & 20 \\
\hline IVDMD leaf (g/kg) & 705 & 699 & 695 & 686 & 697 & 673 & 16 \\
\hline IVDMD stem (g/kg) & 678 & 684 & 654 & 642 & 645 & 660 & 23 \\
\hline IVDMD whole (g/kg) & 701 & 719 & 690 & 687 & 697 & 697 & 16 \\
\hline SR Leaf (kgf) & $3.5^{\mathrm{bc}}$ & $3.3^{c}$ & $4.3^{\mathrm{ab}}$ & $3.7^{\mathrm{bc}}$ & $4.3^{\mathrm{ab}}$ & $4.9^{\mathrm{a}}$ & 0.7 \\
\hline SR Stem (kgf) & 8.0 & 7.8 & 9.6 & 9.2 & 9.2 & 10.4 & 1.6 \\
\hline
\end{tabular}

Grazing frequency affected IVDMD (Table 2$)$ of the stems $(\mathrm{P}=0.013)$ and leaves $(\mathrm{P}=0.014)$, but not the whole forage $(\mathrm{P}=0.211)$. TG resulted in forage with a higher IVDMD in both stems and leaves, with the lowest values found under DG. There was no grazing cycle effect on forage IVDMD in paddocks grazed under TG $\left(\mathrm{P}_{\text {leaf }}=0.143 ; \mathrm{P}_{\text {stem }}=0.110 ; \mathrm{P}_{\text {whole }}=0.149\right)$, or every 28 days $\left(\mathrm{P}_{\text {leaf }}=0.593 ; \mathrm{P}_{\text {stem }}=0.208\right.$; $\left.\mathrm{P}_{\text {whole }}=0.124\right)$. On the DG paddocks there was a cyclic effect (Table 5) on IVDMD of leaves $(\mathrm{P}=0.043)$, but not of stems $(P=0.462)$ or whole forage $(P=0.312)$. Stems and leaves of tropical forage species are often more lignified, and thus more resistant to the penetration of ruminal microorganisms, and this leads to low potential digestibility of leaves. Immature tropical forage species show similar digestibility of stems and leaves, but with increases maturity, stems become less digestible than leaves (Monson et al., 1969). In the present study, stem IVDMD (656 to $660 \mathrm{~g} / \mathrm{kg}$ ) was lower than that of leaves (679 to $693 \mathrm{~g} / \mathrm{kg}$ ). The decrease in digestibility from the first to the second cycle within the DG strategy is probably related to the longer rest period on the second cycle (42 days), whereas the first, third and fourth cycles had rest periods of 31, 28 and 37 days, respectively.

Treatments based on a structural condition of the sward (\% LI) were hypothesized to "standardize" the qualitative characteristics of whole forage (minimal variation over cycles), but the results showed that this was not achieved. Terry \& Tilley (1964) showed that leaf proportion has a low correlation with digestibility, because leaves can have variable digestibility. Probably, for this reason, no differences were found in digestibility of leaves over grazing cycles in the TG strategy (mean $693 \mathrm{~g} / \mathrm{kg}$ ) where pre-graze forage had a higher leaf proportion (93\%). The TG management produced forage with a higher nutritive value, with a higher concentration of CP in the stems and whole forage, lower concentration of NDF and ADF in the stems, and higher IVDMD of leaves and stems. The DG and 28-d treatments produced forage with a lower nutritive values, whereas the higher grazing frequency (TG) resulted in shorter rest periods (22 days on 
average), more grazing cycles (Pedreira et al., 2007), forage with high leaf proportions (Pedreira et al., 2009) and higher photosynthetic capacity at the initial phase of re-growth (Pedreira \& Pedreira, 2007).

Table 4 Grazing cycle effect on qualitative responses of Xaraes palisadegrass forage (leaf and stem fractions, and whole forage) grazed every 28 days (Dry matter basis)

\begin{tabular}{lcccccc}
\hline \multirow{2}{*}{ Response } & \multicolumn{5}{c}{ Grazing cycle } & \multirow{2}{*}{ s.e.m. } \\
\cline { 2 - 5 } & 1 & 2 & 3 & 4 & 5 & \\
\cline { 2 - 6 } CP leaf (g/kg) & $155^{\mathrm{a}}$ & $126^{\mathrm{b}}$ & $106^{\mathrm{c}}$ & $121^{\mathrm{b}}$ & $103^{\mathrm{c}}$ & 20 \\
CP stem (g/kg) & $96^{\mathrm{a}}$ & $71^{\mathrm{b}}$ & $60^{\mathrm{bc}}$ & $67^{\mathrm{b}}$ & $55^{\mathrm{c}}$ & 16 \\
CP whole (g/kg) & $134^{\mathrm{a}}$ & $127^{\mathrm{a}}$ & $103^{\mathrm{bc}}$ & $112^{\mathrm{b}}$ & $93^{\mathrm{c}}$ & 16 \\
\hline NDF leaf (g/kg) & 679 & 671 & 695 & 687 & 703 & 20 \\
NDF stem (g/kg) & $734^{\mathrm{c}}$ & $753^{\mathrm{bc}}$ & $762^{\mathrm{b}}$ & $765^{\mathrm{b}}$ & $805^{\mathrm{a}}$ & 27 \\
NDF whole (g/kg) & $673^{\mathrm{b}}$ & $675^{\mathrm{b}}$ & $703^{\mathrm{a}}$ & $706^{\mathrm{a}}$ & $710^{\mathrm{a}}$ & 19 \\
\hline ADF leaf (g/kg) & 350 & 349 & 365 & 354 & 363 & 14 \\
ADF stem (g/kg) & $399^{\mathrm{b}}$ & $407^{\mathrm{b}}$ & $422^{\mathrm{ab}}$ & $421^{\mathrm{ab}}$ & $445^{\mathrm{a}}$ & 20 \\
ADF whole (g/kg) & $357^{\mathrm{ab}}$ & $344^{\mathrm{b}}$ & $368^{\mathrm{a}}$ & $366^{\mathrm{ab}}$ & $367^{\mathrm{a}}$ & 12 \\
\hline IVDMD leaf (g/kg) & 677 & 681 & 667 & 685 & 683 & 14 \\
IVDMD stem (g/kg) & 674 & 643 & 661 & 663 & 640 & 20 \\
IVDMD whole (g/kg) & 705 & 684 & 679 & 690 & 688 & 13 \\
\hline SR Leaf (kgf) & $3.7^{\mathrm{c}}$ & $4.4^{\mathrm{b}}$ & $4.4^{\mathrm{b}}$ & $4.6^{\mathrm{abc}}$ & $5.3^{\mathrm{a}}$ & 0.5 \\
SR Stem (kgf) & $8.6^{\mathrm{b}}$ & $11.2^{\mathrm{a}}$ & $11.8^{\mathrm{a}}$ & $11.8 \mathrm{a}$ & $12.8^{\mathrm{a}}$ & 1.6 \\
\hline
\end{tabular}

${ }^{\mathrm{a}, \mathrm{b}}$ Means within rows with different superscript letters differ significantly at $\mathrm{P}<0.05$.

CP - Crude protein; NDF - Neutral detergent fibre; ADF - Acid detergent fibre; IVDMD - In vitro dry matter digestibility; SR - shearing resistance.

The intended standardization of pre-graze sward conditions in treatments based on light interception did not result on uniformity of qualitative determinants of the forage on offer (i.e. pre-graze, above the stubble), as the TG and DG strategies resulted in differences among grazing cycles, mainly in whole forage. The 28-d treatment, as expected, produced forage that was highly variable, qualitatively.

Strategies affected shearing resistance (Table 6$)$ of the stems $(P=0.001)$, but not of the leaves $(\mathrm{P}=0.162)$. The TG strategy produced forage with stems that were less resistant to shearing. Across grazing cycles the TG treatment (Table 3 ) resulted in uniform shearing resistance of stems $(P=0.363)$, but variable shearing resistance of leaves $(\mathrm{P}=0.022)$. This did not happen in the 28-d treatment (Table 4), where differences were found for leaves $(\mathrm{P}=0.001)$ and stems $(\mathrm{P}=0.002)$. There was no variation in shearing resistance across grazing cycles for stems $(P=0.074)$, but there was for leaves $(P=0.001)$ on pastures subjected to the DG strategy (Table 5). There was no difference in grinding resistance of the leaves $(\mathrm{P}=0.701)$ or whole forage $(\mathrm{P}=0.067)$.

Paddocks under the TG strategy produced forage that was less resistant to shearing in both the stems and leaves. This forage was younger, since the rest periods were, on average, 22 days. This lower shearing resistance of stems would likely favour a higher forage intake rate, as shearing resistance has been shown to be highly correlated with intake (Minson \& Wilson, 1994). With increased maturity, shearing resistance also increased. Nave et al. (2009) established canonical correlations among chemical, morphological and physical characteristics of Xaraes palisadegrass and found that forage with lower shearing resistance in leaves 
Table 5 Grazing cycle effect on qualitative responses of Xaraes palisadegrass forage (leaf and stem fractions, and whole forage) under the "delayed grazing” (DG) strategy (Dry matter basis)

\begin{tabular}{|c|c|c|c|c|c|}
\hline \multirow{2}{*}{ Response } & \multicolumn{4}{|c|}{ Grazing cycle } & \multirow{2}{*}{ s.e.m. } \\
\hline & 1 & 2 & 3 & 4 & \\
\hline CP leaf (g/kg) & $151^{\mathrm{a}}$ & $115^{\mathrm{b}}$ & $153^{\mathrm{a}}$ & $113^{\mathrm{b}}$ & 23 \\
\hline CP stem (g/kg) & $94^{\mathrm{ab}}$ & $69^{\mathrm{bc}}$ & $87^{\mathrm{a}}$ & $62^{\mathrm{C}}$ & 18 \\
\hline CP whole (g/kg) & $137^{\mathrm{a}}$ & $105^{\mathrm{b}}$ & $139^{\mathrm{a}}$ & $108^{\mathrm{b}}$ & 21 \\
\hline NDF leaf (g/kg) & $676^{\mathrm{a}}$ & $714^{\mathrm{a}}$ & $679^{\mathrm{a}}$ & $683^{\mathrm{a}}$ & 26 \\
\hline NDF stem (g/kg) & $767^{\mathrm{a}}$ & $774^{\mathrm{a}}$ & $754^{\mathrm{a}}$ & $782^{\mathrm{a}}$ & 15 \\
\hline NDF whole (g/kg) & $680^{\mathrm{a}}$ & $698^{\mathrm{a}}$ & $673^{\mathrm{a}}$ & $676^{\mathrm{a}}$ & 25 \\
\hline ADF leaf (g/kg) & $354^{\mathrm{b}}$ & $372^{\mathrm{a}}$ & $352^{b}$ & $341^{\mathrm{b}}$ & 14 \\
\hline ADF stem (g/kg) & $407^{\mathrm{a}}$ & $429^{\mathrm{a}}$ & $405^{\mathrm{a}}$ & $416^{\mathrm{a}}$ & 16 \\
\hline ADF whole (g/kg) & $354^{\mathrm{a}}$ & $352^{\mathrm{a}}$ & $350^{\mathrm{a}}$ & $349^{a}$ & 15 \\
\hline IVDMD leaf (g/kg) & $686^{\mathrm{ab}}$ & $665^{\mathrm{b}}$ & $699^{\mathrm{a}}$ & $671^{\mathrm{b}}$ & 18 \\
\hline IVDMD stem (g/kg) & $650^{\mathrm{a}}$ & $634^{\mathrm{a}}$ & $639^{\mathrm{a}}$ & $618^{\mathrm{a}}$ & 23 \\
\hline IVDMD whole (g/kg) & $705^{\mathrm{a}}$ & $679^{\mathrm{a}}$ & $696^{\mathrm{a}}$ & $699^{a}$ & 17 \\
\hline SR Leaf (kgf) & $3.9^{c}$ & $4.8^{\mathrm{b}}$ & $3.9^{c}$ & $5.3^{\mathrm{a}}$ & 0.7 \\
\hline SR Stem (kgf) & 10.0 & 11.7 & 9.1 & 11.3 & 1.4 \\
\hline
\end{tabular}

${ }^{\mathrm{a}-\mathrm{c}}$ Row means with different superscripts differ significantly at $\mathrm{P}<0.05$.

CP - Crude protein; NDF - Neutral detergent fibre; ADF - Acid detergent fibre; IVDMD - In vitro dry matter digestibility; SR - shearing resistance.

Table 6 Shearing resistance ( \pm s.e.) of Xaraes palisadegrass forage components (leaf and stem) under three different grazing strategies ( $n=6,4$, and 5, for TG, DG, and 28-d, respectively)

\begin{tabular}{lcc}
\hline \multirow{2}{*}{ Strategy } & Leaf & Stem \\
\cline { 2 - 3 } & SR (kgf) & SR (kgf) \\
\hline \multirow{2}{*}{ TG } & $4.00 \pm 0.14$ & $9.01^{\mathrm{b}} \pm 0.37$ \\
DG & $4.48 \pm 0.24$ & $10.51^{\mathrm{a}} \pm 0.47$ \\
$28-\mathrm{d}$ & $4.38 \pm 0.14$ & $11.16^{\mathrm{a}} \pm 0.39$ \\
& & \\
\hline Column means with different superscripts differ significantly at $\mathrm{P}<0.05$
\end{tabular}

and stems had higher concentrations of crude protein in the leaves and whole forage, lower concentrations of NDF in the leaves and whole forage, and higher digestibility of the leaves and stems. Hughes et al. (1998) studied shearing resistance of leaves in four species of Brachiaria spp., sampled at two maturities (4 and 6 weeks), and found differences among species $(B$. brizantha $=2.73 \mathrm{kgf}, B$. humidicola $=1.9 \mathrm{kgf}$, $B$. decumbens $=1.4 \mathrm{kgf}$ and $B$. ruziziensis $=1.2 \mathrm{kgf}$ ) but not between maturities, which is consistent with our results.

In the present work, we studied a single material under three treatments, and grinding resistance did not differ among treatments or grazing cycles. Herrero et al. (2001) studied physical characteristics and their 
relationship with chemical composition of B. brizantha, B. ruziziensis, B. humidicola and B. decumbens, and found no correlation between shearing resistance and grinding resistance. One advantage of shearing resistance as an indication of nutritive value is that it can be measured when the forage is still fresh, keeping intact the anatomical structure of plant parts as well as the cell wall constituents; whereas grinding resistance evaluation uses dried and coarsely ground samples (Wilson, 1997; Wilson \& Hatfield, 1997). This is important in the determination of physical descriptors of the forage, as tissue integrity and fibre characteristics may be lost in analysis of dried material. For the physical characterisation methods evaluated, shear strength showed more consistent results when compared to grinding resistance. The TG strategy produced forage that was less resistant to shearing in stems, characterizing younger stems.

\section{Conclusions}

Grazing strategies based on light interception did not produce forage with a uniform nutritive value at pre-graze. The use of the TG strategy resulted in more grazing cycles (younger forage) and produced forage with less stem and better nutritive value. Longer rest periods (DG and 28-d) decreased the leaf proportion and nutritive value of the forage on offer. This can be a valuable alternative for forage systems where animals have high nutritional requirements (lactating cows or growing beef animals). When a high yield (forage mass and accumulation) is needed. However, longer intervals (DG) may be advantageous, allowing for high stocking rate, despite lower forage nutritive value. Further research is needed to quantify qualitative responses of Xaraes palisadegrass under controlled sward conditions and rotational grazing, as well to quantifying animal responses, including voluntary intake and performance.

\section{Acknowledgements}

Thanks are due to FAPESP (Fundação de Amparo à Pesquisa do Estado de São Paulo) for granting a graduate scholarship to the first author.

\section{References}

Braga, G.J., Pedreira, C.G.S., Portela, J.N., Leite, V.B.O. \& Oliveira, E.A., 2009. Herbage yield of signalgrass pastures as affected by grazing management. S. Afr. J. Anim. Sci. 39 (Suppl.1), 130-132.

Carnevalli, R.A., Da Silva, S.C. \& Bueno, A.A.O., 2006. Herbage production and grazing losses in Panicum maximum cv. Mombaça under four grazing managements. Trop. Grassl. 40, 165-176.

Da Silva, S.C. \& Sbrissia, A.F., 2000. The forage plant on the production system. In: The Forage Plant on the Production System. Eds Peixoto, A.M., Pedreira, C.G.S., Moura, J.C. \& Faria V.P., FEALQ, Piracicaba, SP, Brazil. pp. 3-20. (in Portuguese).

Euclides, V.P.B., 2002. Supplementation strategies on pasture: a critical view. In: Proceedings of the Symposium on strategic management of grazing. Eds Pereira, O.J., Obeid, J.A., Nascimento Júnior, D. \& Fonseca, D.M., UFV, Vicosa, Brazil, pp.437-469. (in Portuguese).

Euclides, V.P.B., Cardoso, E.G., Macedo, M.C.M. \& Oliveira, M.P. 2000. Voluntary Intake of Brachiaria decumbens cv. Basilisk and Brachiaria brizantha cv. Marandu under Grazing. Rev. Bras. Zootec. 29, 2200-2208. (in Portuguese, English abstract).

Flores, R.S., Euclides, V.P.B., Abrão, M.P.C., Galbeiro, S., Difante, G.S. \& Barbosa, R.A., 2008. Animal performance, forage yield and structural characteristics in the palisadegrass cvs. Marandu and Xaraes submitted to grazing intensities. Rev. Bras. Zootec. 37, 1355-1365 (in Portuguese, English abstract).

Giger-Riverdin, S., 2000. Characterization of feedstuffs for ruminants using some physical parameters. Anim. Feed Sci. Technol. 82, 53-69.

Herrero, M., Valle, C.B., Hughes, N.R.G., Sabatel, V.O. \& Jessop, N.S., 2001. Measurements of physical strength and their relationship to the chemical composition of four species of Brachiaria. Anim. Feed Sci. Technol. 92, 149-158.

Holden, L.A., 1999. Comparison of methods of in vitro dry matter digestibility for ten feeds. J. Dairy Sci. 2, 1791-1794.

Hughes, R.G., Valle, C.B., Sabatel, V.O., Boock, J., Jessop, N.S. \& Herrero, M., 2000. Shearing strength as an additional selection criterion for quality in Brachiaria pastures ecotypes. J. Agric. Sci. 135, 123-130. 
Hughes, R.G., Valle, C.B. \& Herrero, M., 1998. Estimativa de resistência ao cisalhamento e à moagem em quatro espécies de Brachiaria. In: Reunião Anual da Sociedade Brasileira de Zootecnia. pp. 43-45. (in Portuguese, English abstract).

Littell, R.C., Milliken, G.A., Stroup, W.W., Wolfinger, R.D. \& Schabenberger, O., 2006. SAS System for Mixed Models. 2.ed. SAS Institute Inc. 813 p.

Mackinnon, B.W., Faston, H.S., Barry, T.N. \& Sedcole, J.R., 1988. The effect of reduced leaf shear strength on the nutritive value of perennial ryegrass. J. Agric. Sci. 3, 469-474.

Mari, L.J., Nussio, L.G., Pedroso, A.F. \& Schmidt, P., 2003. Effects of harvesting frequency and year season on the chemical composition of Marandu grass (Brachiaria brizantha) silage. In: IX World Conference on Animal Production. Proc. IX World Conference on Animal Production, CD-ROM.

Minson, D.J. \& Cowper, J.L., 1974. An integrating wattmeter for measuring the energy used to grind pasture samples. J. Br. Grassl. Soc. 29, 133-135.

Minson, D.J. \& Wilson, J.R., 1994. Prediction of intake as an element of forage quality. In: Forage quality, evaluation and utilization. Eds. Fahey, G.C., Collins, M., Moser, L.E. \& Mertens, D.R. ASA-CSSASSSA, Madison, WI, USA, 4, 533-563.

Monson, W.G., Lowrey, R.S. \& Forbes, I., 1969. In vitro nylon bags vs. two stages in vitro digestion: Comparison of two techniques for estimating dry matter digestibility of forages. Agron. J. 61, 587-589.

Nave, R.L.G., Pedreira, C.G.S. \& Lima, C.G., 2009. Canonical correlations among chemical, physical and morphological characteristics of Xaraes palisadegrass under rotational grazing. Sci. Agric. 66, 270-275.

Pedreira, B.C., Pedreira, C.G.S. \& Da Silva, S.C., 2009. Herbage accumulation during regrowth of Xaraes palisadegrass submitted to rotational stocking strategies. Rev. Bras. Zootec, 38, 618-625. (in Portuguese, English abstract).

Pedreira, B.C., Pedreira, C.G.S. \& Da Silva, S.C., 2007. Sward structure and herbage accumulation in Brachiaria brizantha cultivar Xaraes in response to strategies of grazing. Pesqui. Agropecu. Bras. 42, 281-287. (in Portuguese, English abstract).

Pedreira, B.C. \& Pedreira, C.G.S., 2007. Leaf photosynthesis in Xaraes palisadegrass [Brachiaria brizantha (A. Rich.) Stapf. cv. Xaraes] and modeling canopy assimilatory potential under rotational stocking strategies. Rev. Bras. Zootec. 36, 773-779. (in Portuguese, English abstract).

Sinclair, T.R. \& Selligman, N.G., 1995. Global environment change and simulated forage quality of wheat. I. Nonstressed conditions. Field Crop. Res. 40, 19-27.

Soil Survey Staff, 2006. Keys to Soil Taxonomy. USDA-Natural Resources Conservation Service. Washington, D.C., USA.

Terry, R.A. \& Tilley, J.M.A., 1964. The digestibility of the leaves and stems of perennial ryegrass, cocksfoot, timothy, tall fescue, lucerne and sainfoin, as measured by in vitro procedure. J. Br. Grassl. Soc. 19, 363-372.

Tilley, J.M.A. \& Terry, R.A., 1963. A two-stage technique for the in vitro digestion of forage crops. J. Br. Grassl. Soc. 18, 104-111.

Welles, J.M. \& Norman, J.M., 1991. Instrument for indirect measurement of canopy architecture. Agron. J. 83, 818-825.

Wiles, P.G., Gray, I.K. \& Kissling, R.C., 1998. Routine analysis of protein by Kjeldahl and Dumas methods: review and interlaboratory study using dairy products. J. AOAC Int. 81, 620-632.

Wilson, J.R., 1993. Organization of forage plant tissues. In: Forage cell wall structure and digestibility. Eds Jung, H.G., Buxton, D.R. \& Hatfields, R.D., ASA-CSSA-SSSA, Madison, WI, USA, pp.1-32.

Wilson, J.R., 1997. Structural and anatomical traits of forage influencing their nutritive value for ruminants. In: Simpósio internacional sobre produção animal em pastejo. Universidade Federal de Viçosa, Viçosa, MG, Brazil, pp.173-208.

Wilson, J.R. \& Hatfield, R.D., 1997. Structural and chemical changes of cell wall types during stem development: consequences for fibre degradation by rumen microflora. Aust. J. Agric. Res. 48, 165-180. 